\title{
Analysis of Students 'Mathematic Critical Thinking Ability Through Application of Problem Based Learning Models in Mts Hifzhil Qur'an Medan
}

\author{
Nisa Cahya Pertiwi Lubis, Mulyono, Asrin Lubis \\ Postgraduate Mathematics Education Study Program, State University of Medan
}

\begin{abstract}
This study aims to analyze students' mathematical critical thinking skills through the application of a problembased learning model. The research subjects of class VIII-5 MTs Hifzhil Qur'an Medan, totaling 39 students. The research instrument was a test of mathematical critical thinking skills and interview guidelines. Data analysis was performed using the Miles and Huberman model. The results showed that the students' mathematical critical thinking skills through the application of problem-based learning models obtained that out of 39 students there were 8 students who had high category mathematical critical thinking skills, 14 students who had medium category, and 17 students who had low category. For each indicator, students have an average assessment of interpretive indicators, namely the high category; analysis indicators, namely the medium category; evaluation indicators are low category; and inference is the low category. Student difficulties in completing tests of students' mathematical reasoning abilities a) in the high category, students have difficulty in the criteria of facts and principles; b) in the medium and low categories, students have difficulty in the criteria for facts, principles, and operations.
\end{abstract}

Keywords: Mathematical Critical Thinking, Problem Based Learning Model

DOI: $10.7176 / \mathrm{JEP} / 11-36-02$

Publication date: December $31^{\text {st }} 2020$

\section{PRELIMINARY}

Educating the nation's life is one of the goals of the Indonesian State. This goal is as stated in the preamble of the 1945 Constitution in paragraph four (Grasindo, 2017: 1). One of the efforts to educate the nation's life is through education. This is explained in the National Education System Law (Depdiknas, 2003: 3) that: National education functions to develop capabilities and shape the character and civilization of the nation with dignity in order to educate the life of the nation, aiming at developing the potential of students to become believers and be devoted to God Almighty, have a noble character, are healthy, knowledgeable, capable, creative, independent and become democratic and responsible citizens. Based on the functions and objectives of the National Education System, the intended education system will produce quality human resources who have the ability, character and attitude. Education has a very important role in producing quality human resources (Sundari, 2016: 44). Improving the quality of HR (Human Resources) needs to be pursued in line with the development of Science and Technology (Science and Technology) (Indah, et al, 2019: 417).

In fact, the quality of education and human resources in Indonesia is still low. This can be seen from the HDI (Human Development Index) or HDI (Human Development Index) data released by the United Nations Development Program (2018) which measures the success of education and the effect of economic policies on the quality of human life. From the HDI or HDI data released by UNDP from year to year, there is an increase but it is still classified as medium and far from developed countries. For 2018, Indonesia is still ranked 111 with a value of 0.707 , which is still far from the average value of developed countries, namely 0.875 (UNDP, 2018).

Quality human resources will have the abilities to master information and knowledge amid the advancement of science and technology, these abilities require critical, systematic, logical, and creative thinking (Hasratuddin, 2018: 33). One of the educational programs that can develop critical, systematic, logical and creative thinking skills is mathematics (Wittgenstein in Hasratuddin, 2018: 34).

Based on Permendiknas Number 22 (Depdiknas, 2006: 5) that:

Mathematics needs to be given to all students from elementary to high school to equip students with logical, analytical, systematic, critical, and creative skills as well as independently. This competence is needed so that students can have the ability to acquire, manage, and use information to survive in ever-changing, uncertain, and competitive conditions.

However, in reality, student achievement in mathematics has not been satisfactory at both the national and international levels. PISA (Program for International Student Assessment) is one of the main assessments on an international scale that assesses students' mathematical abilities (Mansur, 2018: 140). Based on the results of the 2015 PISA, it shows that Indonesia's mathematical literacy skills are still very low because Indonesia is ranked 62 out of 72 countries (OECD, 2016: 5). One of the causes of low student achievement in mathematics is because the ability of students to solve problems that require high thinking and reasoning skills is still very low and this is because the learning process that has been applied in schools places more emphasis on students memorizing 
formulas than understanding concepts (Iwan Pranoto in Mahmuzah, 2015: 66).

One of the higher order thinking skills is the ability to think critically. Higher order thinking skills include problem solving, critical thinking, and creative thinking skills (King in Mahmuzah, 2015: 65). Critical thinking is a thought process that aims to make rational decisions that are directed to decide whether to believe or do something (Ennis in Fisher, 2009: 5). From this statement it can be said that critical thinking is focused in terms of something that is full of awareness and leads to a goal. The purpose of critical thinking is to consider and evaluate information that ultimately enables us to make decisions. But in reality, the ability to think critically in mathematics learning is still relatively low, it can be seen from the results of research by Nugraha (2015: 10) which obtained an average pre-test score of 12.43; highest score 17; and the lowest score 9. Research conducted by Happy \& Djamilah (2014: 54) also shows that critical thinking skills are still low during the pre-test with a complete percentage of $3.33 \%$ and $96.67 \%$ incomplete. The fact in the field of critical thinking skills is still low, this is because students still tend not to successfully answer the problems that exist in the non-routine questions given (Tresnawati, et al, 2017: 116). In the learning process, students are less encouraged to develop critical thinking skills, because the learning process in the classroom is directed at the child's ability to memorize (Joyce, 2011: 145).

A possible alternative to improve students' mathematical critical thinking skills is problem-based learning. Arends (2008: 43) states that: PBM (Problem-based learning) is a learning model in which students work on authentic problems with the intention of compiling their own knowledge, developing inquiry and critical thinking skills, developing independence, and self-confidence. Problems in PBM must pay attention to and understand the types of problems given (Barrow in Ismaimuza, 2010: 22). There are two types of problems in general, namely unstructured (ill-structured), contextual and engaging (contextual and engaging) problems. Selection of the types of problems given is expected to stimulate students to ask questions from various perspectives. Through PBM students also learn to be responsible for learning activities, not just passive recipients of information, but must actively seek the information needed according to their capacities. In PBM students are required to ask questions and express opinions, find relevant information from hidden sources, look for various ways (alternatives) to get solutions, and find the most effective way to solve problems.

\section{LITERATURE REVIEW}

\subsection{Critical Thinking Ability}

From the definition of critical thinking according to Ennis, (in Fisher, 2009: 4) the indicators of critical thinking are: focus, reason (Reason), conclusion (Inference), situation (Situation), clarity (Clarity), and direct review ( Overview). Facione (in Filsaime, 2008: 66) suggests six critical thinking skills, namely: (1) Interpretation, namely the ability to understand, explain and give meaning to data or information, (2) Analysis, namely the ability to identify relationships of information used to express thoughts or opinions, (3) Evaluation, namely the ability to test the correctness of information used in expressing thoughts or opinions, (4) Inference, namely the ability to identify and obtain the elements needed to make a reasonable conclusion, (5) Explanation, namely the ability to explain or state the results of thoughts based on evidence, methodology, and context. (6) Self-regulation, namely a person's ability to regulate his thinking.

Based on some of the opinions above, it is concluded that the indicators of mathematical critical thinking skills that will be used in this study are (1) Interpretation, namely the ability to understand, explain and give meaning to data or information, (2) Analysis, namely the ability to identify relationships from information used to express thoughts or opinions, (3) Evaluation, namely the ability to test the correctness of information used in expressing thoughts or opinions, (4) Inference, namely the ability to identify and obtain the elements needed to make a reasonable conclusion.

\subsection{Problem Based Learning}

Bound and Felifi (Rusman, 2011: 230) suggest that the problem-based learning model is the most significant innovation in education. Margetson (Rusman, 2011: 2030) says that the problem-based learning model helps to improve the development of lifelong learning skills in a mindset that is open, reflective, critical and active learning and facilitates successful problem solving, communication, group work, and interpersonal skills. better than other models. 
Table 1 Syntax of Learning Model Based on Problems

\begin{tabular}{|c|l|}
\hline Step & \multicolumn{1}{c|}{ Teacher's Behavior } \\
\hline $\begin{array}{c}\text { Stage-1 } \\
\text { Student orientation to the } \\
\text { problem }\end{array}$ & $\begin{array}{l}\text { The teacher explains the learning objectives, explains the logistics required, } \\
\text { proposes phenomena or demonstrations or stories to raise problems, motivates } \\
\text { students to be involved in solving the selected problem }\end{array}$ \\
\hline $\begin{array}{c}\text { Stage-2 } \\
\text { Organizing students to learn }\end{array}$ & $\begin{array}{l}\text { The teacher helps students define and organize learning tasks related to these } \\
\text { problems }\end{array}$ \\
\hline $\begin{array}{c}\text { Stage-3 } \\
\text { Guiding individual and } \\
\text { group investigations }\end{array}$ & $\begin{array}{l}\text { The teacher encourages students to collect appropriate information, carry out } \\
\text { expressions, to get explanations and problem solving }\end{array}$ \\
\hline $\begin{array}{c}\text { Stage-4 } \\
\text { Develop and present the } \\
\text { work }\end{array}$ & $\begin{array}{l}\text { The teacher assists students in planning and preparing appropriate work such as } \\
\text { reports, videos, and models and helps them to share assignments with friends }\end{array}$ \\
\hline $\begin{array}{c}\text { Stage-5 } \\
\text { Analyze and evaluate the } \\
\text { problem solving process }\end{array}$ & The teacher helps students to reflect or evaluate their investigations and the \\
processes they use
\end{tabular}

Source: Ibrahim, et al (in Rusman, 2011:243)

\section{RESEARCH METHOD}

This type of research used in this research is descriptive qualitative research. Denzim and Lincoln (in Moleong, 2017: 5) state that "qualitative research is research that uses a natural setting, with the intention of interpreting phenomena that occur and are carried out by involving various existing methods". This research has been carried out at MTs Hifzhil Qur'an Medan with the subject, namely students of class VIII-5, amounting to 39 students. The criteria for subject taking are based on the dominant answer pattern in each category of students' mathematical critical thinking abilities. The object of this research is students' mathematical critical thinking abilities through the application of problem-based learning models. The research instrument was a test of mathematical critical thinking skills and interview guidelines.

\section{RESULTS AND DISCUSSION}

In the learning process that has been carried out for four meetings in class VIII-5 MTs Hifzhil Qur'an Medan that students' critical thinking skills are getting better after the application of problem-based learning models compared to conventional learning that has been taught to students previously because during the application of problembased learning models In this study, it can help students plan problem solving, so that they are able to solve problems related to mathematical critical thinking skills. Therefore, problem-based learning models can be used as an alternative learning that can develop students' mathematical critical thinking skills.

The critical thinking ability test is carried out by students individually and is directly supervised by researchers and teachers of MTs Hifzhil Qur'an Medan mathematics. The level of critical thinking skills can be seen in the following table.

Table 2 Results of Students' Mathematical Critical Thinking Ability

\begin{tabular}{|c|c|c|c|c|}
\hline No. & Value Interval & The Number of Students & $\mathbf{\%}$ & Rating Category \\
\hline 1 & $80 \leq$ SKBKM $\leq 100$ & 8 & 20.51 & High \\
\hline 2 & $65 \leq$ SKBKM $<80$ & 14 & 35.90 & Moderate \\
\hline 3 & $0 \leq$ SKBKM $<65$ & 17 & 43.59 & Low \\
\hline \multicolumn{3}{|c|}{89.06} \\
\hline & The highest score & \multicolumn{3}{|c|}{43.75} \\
\hline Lowest Value & \multicolumn{3}{|c|}{65.31} \\
\hline & Range & \multicolumn{3}{|c|}{13.67} \\
\hline & Average & \multicolumn{3}{|c|}{12} \\
\hline
\end{tabular}

Based on Table 2, it can be seen that the level of students' mathematical critical thinking skills with a problembased learning model. There were 8 students in high category $(20.51 \%), 14$ students in medium category $(35.90 \%)$, and 17 students in low category (43.59\%). From Table 2 it can also be seen that there are 17 students who have SKBKM scores $<65$ or are in the low category which in general means that there are 17 students who are only able to complete a maximum of 2 correct questions and 2 other imperfect questions. But in fact there are also students who only one question is correct and 3 others are wrong. In addition, there were also students' answers that were not perfect for all the question numbers. So, if you accumulate the value obtained in the SKBKM range $<65$ which is in the low category.

For students who have a value of $65^{\leq} \mathrm{SKBKM}<80$ there are as many as 14 people, which in general means that there are 6 students who are able to solve 3 correct questions. In fact, the results obtained from the students' 
answers, students can do 3 questions well, but 1 other question is only partially correct so that if the value obtained is accumulated in the range 65-80 which is in the medium category. For students who have the highest score or are in the high category, namely SKBKM 20 there are as many as 8 people.

This means that there are 8 students who are able to complete almost all the tests given well. In fact, the results obtained from the students' answers are that the students have answered 3 questions correctly, but for 1 other question there is an error when the value is accumulated in the SKBKM range. $\geq_{80}$ which is in the high category.

In addition, it was found that the value range of 39 students, namely 45.31 . This shows that the difference between only the answers of students with the highest score and the lowest score is less than 2 questions. However, if it is seen from the standard deviation (13.04) that the average critical thinking ability between one student and another is not up to 1 question. This shows that the difference between students and other students is still acceptable (because the maximum value of 1 question is 25).

Table 3 Percentage of Each Critical Thinking Indicator

\begin{tabular}{|c|c|}
\hline Critical Thinking Indicators & Average Percentage of Value \\
\hline Interpretation & $84.78 \%$ \\
\hline Analysis & $72.76 \%$ \\
\hline Evaluation & $62.02 \%$ \\
\hline Inference & $43.11 \%$ \\
\hline
\end{tabular}

In Table 3 it can be seen that for each indicator, students have an average assessment of the interpretive indicator of $84.78 \%$, which is a high category, which means that on average students are able to understand, explain and give meaning to data or information well. The analysis indicator is $72.76 \%$, which is the medium category, which means that the average student is able to identify the relationship of the information used to express thoughts or opinions. The evaluation indicator is $62.02 \%$, which is a low category, which means that on average students are not able to test the truth of the information used in expressing thoughts or opinions. Inference indicator $43.11 \%$ is a low category, which means that the average student is unable to identify and obtain the elements needed to make a reasonable conclusion.

The analysis of students 'difficulties in completing the critical thinking ability test was obtained from the results of the students' mathematical critical thinking ability tests and interviews related to the student's difficulty criteria, namely (1) facts, (2) concepts, (3) operations, and (4) principles.

Based on the test results of students 'mathematical critical thinking skills which have been categorized into the category of students' mathematical critical thinking skills and the dominant answer pattern, from the 39 students selected 2 students with high category students 'mathematical critical thinking skills, 2 students with middle category students' mathematical critical thinking skills and 2 students with low category students' mathematical critical thinking skills as subjects analyzed qualitatively.

The difficulty of students completing the test of students' mathematical critical thinking skills has four criteria, namely facts, concepts, operations, and principles. For high category students' mathematical critical thinking skills, students experience difficulties in the fact criteria, namely students are not able to change the problem into the correct mathematical form. For students' mathematical critical thinking skills in the medium and low categories, students experience difficulties in the fact criteria, namely students are not able to change the problem into the correct mathematical form and operation, namely students are less able to operate in solving problems.

\section{CONCLUSION}

Students' mathematical critical thinking skills after applying the problem-based learning model found that out of 39 students there were 8 students who had high category mathematical critical thinking skills, 14 students who had medium category, and 17 students who had low category. For each indicator, students have an average assessment of interpretive indicators, namely the high category; analysis indicators, namely the medium category; evaluation indicators are low category; and inference is the low category.

The difficulty of students in completing the test of students' mathematical critical thinking skills in the high category, students have difficulty in the criteria of facts and principles. In the medium and low categories, students have difficulty in the criteria for facts, principles, and operations.

\section{BIBLIOGRAPHY}

Arends, RI 2008. Learning to Teach, Learning to Teach. Seventh Edition Volume Two. Translation by Soedjipto, Helly, P. and Soedjipto, Sri, M. Yogyakarta: Student Library

Ministry of Education. 2003. Law No. 20 of 2003 concerning the National Education System. Jakarta: Depdiknas Ministry of Education. 2006. Regulation of the Minister of National Education Number 22 Year 2006 Concerning Junior Secondary School Content Standards. Jakarta: Depdiknas 
Filsaime, DK 2008. Revealing the Secret of Critical and Creative Thinking. Jakarta: Achievements of the Library Fisher, A. 2009. Critical Thinking: An Introduction. Jakarta: Erlangga

Grasindo, Tim. 2017. UUD 1945 \& Amendments for Students and the General. Jakarta: Gramedia Widiasarana

Happy, N. \& Widjajanti, DB 2014. The Effectiveness of PBL in terms of Mathematical Critical and Creative Thinking Ability, as well as Middle School Student Self-Esteem. Journal of Mathematics Education Research. Volume 1, Number 1

Hasratuddin. 2018. Why You Should Study Mathematics. Medan: Perc Edira

Indah, AL et al. 2019. Modification of the Realistic Mathematics Learning Approach with Task and Forced Learning Strategies. Proceedings of the National Seminar on KALUNI Education, Vol. 2

Ismaimuza, D. 2010. Middle School Students' Critical and Creative Thinking Ability through Problem Based Learning with Cognitive Conflict Strategies. Journal of Technology. eISSN: 2180-3722, ISSN: 0127-9696

Joyce, et al. 2011. Models of Teaching, 8th edition. Yogyakarta: Learning Library

Mahmuzah, R. 2015. Increased Mathematical Thinking Ability of Junior High School Students through Problem Posing Approach. Journal of Opportunities, Vol. 4, No. 4

Mansur, N. 2018. Training Students' Mathematical Literacy with PISA Questions. Prism1.http://journal.unnes.ac.id/sju/index.php/prisma/

Moleong, L. 2017. Qualitative Research Methodology, Publisher: PT Remaja Rosdakarya

Nugraha, TS \& Mahmudi, A. The Effectiveness of Problem-Based Learning and Problem Posing in terms of Logical and Critical Thinking Ability. Journal of Mathematics Education Research. Online ISSN: 2477-1503

OECD. 2016. PISA 2015 Assessment and Analytical Framework: Mathematics, Reading, Science, Problem Solving and Financial Literacy. Paris: OECD Publishing

Rusman. 2011. Learning Models Developing Teacher Professionalism. Jakarta: Rajawali Press

Sundari. 2016. Improving Student Learning Outcomes in Mathematics Learning through the Savi Approach to Class VB Students of SDIT Al-Izzah Sorong. Journal of Educational Sciences, Vol. 5, No. 2

Tresnawati, et al. 2017. Mathematical critical thinking skills and high school student confidence. Pasundan Journal of Research in Mathematics Learning and Education. Volume 2, No. 2

United Nations Development Program. 2018. Human Development Index Ranking. New York City: UNDP 